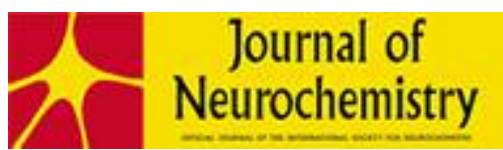

\title{
MONOAMINE OXIDASE-A MODULATES APOPTOTIC CELL DEATH INDUCED BY STAUROSPORINE IN HUMAN NEUROBLASTOMA CELLS
}

\begin{tabular}{|r|l|}
\hline Journal: & Journal of Neurochemistry \\
\hline Manuscript ID: & JNC-E-2007-0379.R2 \\
\hline Manuscript Type: & Original Article \\
\hline Date Submitted by the & 26-Jul-2007 \\
\hline Complete List of Authors: & $\begin{array}{l}\text { Fitzgerald, Julia; Nottingham Trent University, School of Biomedical } \\
\text { and Natural Sciences } \\
\text { Ufer, Christoph; Nottingham Trent University, School of Biomedical } \\
\text { and Natural Sciences } \\
\text { De Girolamo, Luigi; Nottingham Trent University, School of } \\
\text { Biomedical and Natural Sciences } \\
\text { Kuhn, Hartmut; University Medicine Berlin-Charité, , Institute of } \\
\text { Biochemistry } \\
\text { Billett, E.; Nottingham Trent University, School of Biomedical and } \\
\text { Natural Sciences }\end{array}$ \\
\hline Keywords: & $\begin{array}{l}\text { monoamine oxidase-A, apoptosis, SH-SY5Y, staurosporine, } \\
\text { caspase, reactive oxygen species }\end{array}$ \\
\hline
\end{tabular}

\section{ScholarONE" Manuscript Central}




\title{
MONOAMINE OXIDASE-A MODULATES APOPTOTIC CELL DEATH INDUCED BY STAUROSPORINE IN HUMAN NEUROBLASTOMA CELLS
}

Julia C. Fitzgerald, * Christoph Ufer, * Luigi A. De Girolamo, * Hartmut Kuhn, ${ }^{\dagger}$ and E.

\section{Ellen Billett*}

\footnotetext{
* School of Biomedical and Natural Sciences, Nottingham Trent University, Clifton, Nottingham, NG11 8NS, U. K.

'Institute of Biochemistry, University Medicine Berlin-Charité, Monbijoustr. 2, D-10117, Berlin, F. R. Germany.
}

\begin{abstract}
Address correspondence to: Professor Ellen, E. Billett, School of Biomedical and Natural Sciences, Nottingham Trent University, Clifton lane, Clifton, Nottingham, NG11 8NS. U.K, Tel. $\quad(+44) 115$ 8486356; Fax. $\quad(+44) 115$ 8486355; E-Mail: ellen.billett@ntu.ac.uk
\end{abstract}




\begin{abstract}
:
Monoamine oxidases (MAOs) are mitochondrial enzymes which control the levels of neurotransmitters in the brain and dietary amines in peripheral tissues via oxidative deamination. MAO has also been implicated in cell signalling. In this study we describe the MAO-A isoform as functional in apoptosis induced by staurosporine (STS) in human dopaminergic neuroblastoma cells (SH-SY5Y). Increased levels of MAO-A activity were induced by STS, accompanied by increased MAO-A protein and activation of the initiator of the intrinsic pathway, caspase-9, and the executioner caspase-3. MAO-A mRNA levels were unaffected by STS, suggesting that changes in MAO-A protein are due to post-transcriptional events. Two unrelated MAO-A inhibitors reduced caspase activation. STS treatment resulted in sustained activation of the MAPK pathway enzymes extracellular regulated kinase, c-jun terminal kinase and p38, and depletion of the anti-apoptotic protein Bcl-2. These changes were significantly reversed by MAO inhibition. Production of reactive oxygen species (ROS) was increased following STS exposure, which was blocked by both MAO inhibition and the antioxidant $\mathrm{N}$ acetylcysteine. Therefore our data provide evidence that MAO-A, through its production of ROS as a by-product of its catalytic activity on the mitochondrial surface, is recruited by the cell to enhance apoptotic signalling.
\end{abstract}

Key words: Monoamine oxidase-A; apoptosis; SH-SY5Y; staurosporine; caspase; Reactive oxygen species.

Running title: Monoamine oxidase A in neuronal apoptosis 


\section{INTRODUCTION}

Monoamine oxidase (MAO. EC 1.4.3.4) is a flavoenzyme tightly associated with the outer mitochondrial membrane. There are two forms (MAO-A and MAO-B) with $70 \%$ amino acid homology, coded for by two separate genes on the $\mathrm{X}$ chromosome (Bach et al. 1988). Monoamine oxidases metabolise amines to their corresponding aldehydes, with hydrogen peroxide $\left(\mathrm{H}_{2} \mathrm{O}_{2}\right)$ and ammonia as by-products. MAO controls neurotransmitter levels and intracellular amine stores. The two isoforms have distinct substrate and inhibitor specificities, with MAO-A, for example, preferentially deaminating 5-hydroxytryptamine (serotonin, 5-HT) and inhibited by low concentrations of clorgyline (Fowler and Tipton, 1984). The MAO isoforms are differentially expressed in the CNS and peripheral tissues (reviewed by Billett, 2004). In human brain MAO-A is highly expressed in catecholaminergic neurons, including the dopaminergic neurons of the substantia nigra pars compacta (SNpc). In contrast, MAO-B is found in serotonergic neurons and astrocytes. It has been suggested that age-related increases in glial MAO-B expression may contribute to the aetiology of Parkinson's disease (PD) (Kumar et al. 2003) whilst MAO-A deficiency leads to aggressive behaviour in mice and humans (Shih et al. 1999).

Oxidative stress results from an imbalance of antioxidant defence mechanisms and generation of reactive oxygen species (ROS). ROS are important mediators in an array of biological processes, including cell growth (Yoon et al. 2002), cell signalling and apoptosis (Finkel, 1998). ROS have been implicated in various forms of cell death (Tatton and Olanow, 1999), and a range of pathological conditions including neurodegeneration (Schulz et al. 2000). Oxidative stress has particular relevance to $\mathrm{PD}$, a disorder that causes damage to nigrostriatal dopaminergic neurons, 
because dopamine itself can undergo autooxidation which can result in structural modification of proteins (Stokes et al. 1999) and have deleterious effects on cellular respiration (Berman and Hastings, 1999). Vulnerability of neurons to attack by free radicals is heightened by their low glutathione content, which in PD is further reduced (Riederer et al. 1989).

A major source of ROS in the cell is the mitochondrial generation of superoxide anion due to respiration (Abou-Sleiman et al. 2006). In addition, oxidative deamination of biogenic amines by MAO is a key contributor to increased steady state concentrations of ROS (Cadenas and Davies, 2000). In dopaminergic neurons extravesicular dopamine is metabolised by MAO to produce $\mathrm{H}_{2} \mathrm{O}_{2}$, which is further converted to hydroxyl radicals. Metabolism of amines by MAO causes oxidative damage to mitochondrial DNA (Hauptmann et al. 1996) and directly damages the electron transport system and affects antioxidant defence systems (Cohen and Kesler, 1999). Additionally, subtle increases in $\mathrm{H}_{2} \mathrm{O}_{2}$ production caused by up-regulation of MAO-B in the rat neuroblastoma cell line PC12 decreased mitochondrial complex I activity (Kumar et al. 2003).

The role of MAO-A in dopaminergic cell death has been the focus of recent publications. It was reported that induction of apoptosis by nerve growth factor deprivation in rat PC12 cells was paralleled by an increase in MAO-A expression (DeZutter and Davis, 2001). This regulatory process involved the p38 MAPK signal transduction pathway. On the contrary, MAO-A has been found to be a target of a dopaminergic neurotoxin, N-methyl-R-salsolinol, and that in this case inhibition of MAO led to apoptosis in the human neuroblastoma SH-SY5Y cell line (Yi et al. 2006). Most recently, Ou and co-workers (Ou et al. 2006) have reported that growth factor deprivation via serum withdrawal led to a concomitant reduction in the transcription repressor 
R1 (RAM2/CDCA7L/JPO2), increase in MAO-A expression (and activity) in SH-SY5Y cells, and that inhibition of MAO activity prevented loss of cell viability.

In order to explore whether MAO-A is a key player in neuronal apoptosis we tested its impact in another well established apoptotic model (staurosporine treated SH-SY5Y cells; Lopez and Ferrer, 2000). Staurosporine is an unspecific protein kinase inhibitor which has frequently been used as an inducer of the mitochondrial apoptotic pathway (Lopez and Ferrer, 2000). In this study we monitored apoptosis via analysis of caspase activation and explored whether apoptosis was linked to changes in MAO expression and activity, and how ROS and the MAPK pathways were contributing to apoptotic cell signalling.

\section{MATERIALS AND METHODS}

\section{Materials}

SH-SY5Y neuroblastoma cells were obtained from the European Collection of Animal

Cell Cultures (Salisbury, UK). Staurosporine (STS), Acetyl-Asp-Glu-Val-Asp-7amidomethylcoumarin (caspase-3 fluorogenic substrate), ${ }^{14-} \mathrm{C}$-labelled tyramine hydrochloride, clorgyline, deprenyl, tranylcypromine, N-acetylcysteine (NAC), Dulbecco's Modified Eagles Medium (DMEM) HAM's-F12 (1:1), Hank's Buffered Salt Solution, 3,3' diaminobenzidine, anti-Bcl-2 monoclonal antibody, 3-(4,5-dimethylthiazol-2-yl)-2,5-diphenyltetrazolium bromide and ascorbic acid (vitamin C) were purchased from Sigma Aldrich (Dorset, U.K). 2`, 7`Dichlorodihydrofluorecein diacetate (DCDHF) was obtained from Alexis Biochemicals (Nottingham, UK). Anti-active caspase-8 and anti-active caspase-9 antibodies were purchased from Upstate Biotechnology (Hampshire, UK). Anti-phosphorylated ERK, total ERK and anti- 
phosphorylated JNK antibodies were purchased from Santa Cruz Biotechnology (Wiltshire, UK). Anti-phosphorylated p38 and total JNK antibodies were from Cell Signalling Technology (Hertfordshire, UK). Total p38 antibody was purchased from New England Biolabs (MA, U.S.A). Anti-MAO-A (6G11-E1) and anti-MAO-B (3F12-G10-2E3) monoclonal antibodies were made in our laboratory. Secondary antibodies were purchased from DakoCytomation (Cambridgeshire, UK). Oligonucleotides were obtained from Biotez (Berlin, Germany).

\section{Cultures}

Human neuroblastoma SH-SY5Y cells were seeded at a density of approximately $4 \times 10^{4}$ cells $/ \mathrm{cm}^{2}$ on plastic culture plates, flasks (Starsted, Nümbrecht, Germany) or Lab-Tek® chamber slides (NUNC, Roskilde, Denmark) and grown to 75-80 \% confluence in DMEM HAM's-F12 medium containing $10 \%$ (v/v) foetal bovine serum, $2 \mathrm{mM} \mathrm{L-glutamine,} 1 \%$ (v/v) non-essential amino acid solution, 100 units $\mathrm{ml}^{-1}$ penicillin and $100 \mu \mathrm{g} \mathrm{ml} \mathrm{g}^{-1}$ streptomycin at $37^{\circ} \mathrm{C}$ in a $5 \% \mathrm{CO}_{2}$ humidified atmosphere.

\section{Fluorogenic caspase-3 activation assay}

Caspase activity was monitored using a fluorogenic based assay with Acetyl-Asp-GluVal-Asp-7-amidomethylcoumarin (Ac-DEVD-AMC) as substrate. Briefly, 500,000 cells were seeded into $25 \mathrm{~cm}^{3}$ flasks. On reaching $70-80 \%$ confluence the cells were pre-incubated for $2 \mathrm{~h}$ with the required inhibitor then treated for $0-8 \mathrm{~h}$ with STS. After treatment both adherent and floating cells were harvested by centrifugation at $300 \times \mathrm{g}$ for $5 \mathrm{~min}$. The pellet was washed twice with DMEM, resuspended in 200-300 $\mu$ l lysis buffer (50 mM HEPES, 5 mM CHAPS, 5 mM DTT, $\mathrm{pH} 7.4$ ) and incubated on ice for $20 \mathrm{~min}$. The lysates were centrifuged at $200 \times \mathrm{g}$ at $4{ }^{\circ} \mathrm{C}$ for 
5 min to remove cell debris. The assay was prepared in triplicate. Cell lysates were transferred to black 96-well plates and made up to $80 \mu \mathrm{l}$ with assay buffer $(20 \mathrm{mM}$ HEPES pH 7.4, 0.1\% [w/v] CHAPS, $5 \mathrm{mM}$ dithiothreitol, $2 \mathrm{mM}$ EDTA). Reactions were initiated by the addition of ACDEVD-AMC to a final concentration of $200 \mu \mathrm{M}$ in a total reaction volume of $100 \mu 1$. Fluorescence was measured (excitation $450 \mathrm{~nm}$, emission $360 \mathrm{~nm}$ ) every $20 \mathrm{~min}$ for $4 \mathrm{~h}$ at $37^{\circ} \mathrm{C}$. Data were normalised for protein content, which was determined by the Lowry method (Lowry et al. 1951) and expressed as $\Delta$ fluorescence units $/ \mathrm{min} / \mu \mathrm{g}$ protein.

\section{MTT reduction assay}

SH-SY5Y cells were plated in 96-well plates at a density of $\sim 20,000$ cells/well and grown to $\sim 70-80 \%$ confluence. Cell viability was determined by the 3-(4,5-dimethylthiazol-2yl)-2,5-diphenyltetrazolium bromide (MTT) reduction assay. Briefly, following pre-treatment for $2 \mathrm{~h}$ with the required inhibitors, the cells were treated with $1 \mu \mathrm{M}$ STS in the presence and absence of the MAO inhibitors. MTT stock solution in phosphate-buffered saline was added to each well at a final concentration of $0.5 \mathrm{mg} / \mathrm{ml}$ and incubated for $30 \mathrm{~min}$. The dark blue formazan crystals formed in intact cells were solubilised in $100 \mu \mathrm{l}$ of dimethylsulfoxide and the absorbance measured at $595 \mathrm{~nm}$ with a microtitre plate reader (Bio-Rad model 680, California, U.S.A). Results are expressed as mean percent MTT reduction of the relevant control.

\section{MAO activity assay}

MAO activity was monitored using a radiometric assay with ${ }^{14} \mathrm{C}$-labelled tyramine hydrochloride as substrate, based on the method of Russell and Mayer (Russell and Mayer, 1983) with modifications. Treated cells were harvested as previously described and resuspended in 200

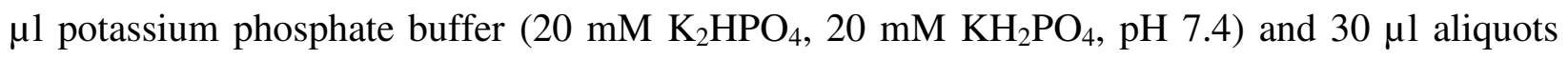


transferred to scintillation vials, in triplicate. Samples were made up to $200 \mu \mathrm{l}$ with potassium phosphate buffer and then incubated at $37^{\circ} \mathrm{C}$ for $5 \mathrm{~min}$. Sample blanks were prepared in parallel containing, in addition, $200 \mu \mathrm{l} 0.5 \mathrm{M} \mathrm{HCl}$. To each sample $20 \mu 11 \mathrm{mM}{ }^{14} \mathrm{C}$-labelled tyramine hydrochloride $(1 \mathrm{mCi} / \mathrm{mmol})$ was added and incubated for $1 \mathrm{~h}$ at $37^{\circ} \mathrm{C}$. The reaction was stopped by the addition of $200 \mu \mathrm{l} 0.5 \mathrm{M} \mathrm{HCl}$. Finally, $3 \mathrm{ml}$ scintillant (1:1 Ethyl acetate: toluene, $1 \%$ [w/v] PPO) was added to each vial, and a sample of the organic phase containing the product transferred into a scintillation vial. MAO activity was measured in a liquid scintillation counter (Cambera-Packard, Schwadorf, Germany). Preliminary assays were undertaken to ensure that MAO activity was linear beyond the $1 \mathrm{~h}$ time point. Data were normalised for protein content, which was determined by the Lowry method (Lowry et al. 1951) and rates expressed as $\mathrm{pmoles} / \mathrm{min} / \mathrm{mg}$ protein.

\section{Gel Electrophoresis and Western blotting}

Cells exposed to STS in the presence and absence of inhibitors were extracted into extraction buffer (50 mM Tris, $5 \mathrm{mM}$ EDTA, $150 \mathrm{mM} \mathrm{NaCl}, 1 \mathrm{mM}$ sodium orthovanadate, 2 mM PMSF, $1 \%$ [w/v] SDS, and $0.2 \%$ [v/v] protease inhibitor cocktail) and immediately boiled for $5 \mathrm{~min}$. Equal protein aliquots $(100 \mu \mathrm{g}$ for analysis of MAPK proteins and $20 \mu \mathrm{g}$ for all others) per sample were subjected to electrophoresis on a $12 \%(\mathrm{v} / \mathrm{v})$ SDS-polyacrylamide gel. Separated proteins were transferred onto a nitrocellulose membrane and equal protein loading assessed by staining with $0.05 \%(\mathrm{w} / \mathrm{v})$ copper phthalocyanine in $12 \mathrm{mM} \mathrm{HCl}$, checked by immunodetection of tERK, tJNK or tP38. Blotted membranes were blocked for $1 \mathrm{~h}$ in either $3 \%(\mathrm{w} / \mathrm{v})$ BSA (for detection of phosphorylated proteins) or $3 \%(\mathrm{w} / \mathrm{v})$ dried skimmed milk (for other proteins) in TBS containing $0.1 \%(\mathrm{v} / \mathrm{v})$ Tween-20 and incubated overnight at $4^{\circ} \mathrm{C}$ with primary antibodies. Membranes were washed and incubated for $2 \mathrm{~h}$ at room temperature with peroxidase-conjugated 
anti-mouse or anti-rabbit immunoglobulin $\mathrm{G}$ (dilution 1:1000). Antibody binding was revealed with the ECL Western blotting detection reagent (Pierce, Rockford, Illinois, and U.S.A). Digital images were captured using a LAS-3000 image-analyser (Fuji Film Co. Ltd., Tokyo, Japan), and band intensity quantified using Aida software (Raytest GmbH, Straubenhardt, Germany).

\section{Dot blotting}

Treated cells were harvested, as previously described, and resuspended in $150 \mu \mathrm{MAO}$ extraction buffer $(50 \mathrm{mM}$ Tris, $150 \mathrm{mM} \mathrm{NaCl}, 5 \mathrm{mM}$ EDTA, $1 \mathrm{mM} \mathrm{Na}$ orthovanadate, $0.5 \%$ [w/v] Triton X-100, $2 \mathrm{mM} \mathrm{PMSF}$ and $0.2 \%[\mathrm{v} / \mathrm{v}]$ protease inhibitor cocktail) and incubated on ice for $20 \mathrm{~min}$. Samples were centrifuged for $10 \mathrm{~min}$ at $300 \times \mathrm{g}$ at $4^{\circ} \mathrm{C}$. The supernatants were sonicated $(3 \times 3$ second pulses at $60 \mathrm{~Hz})$. Equal protein samples, in triplicate, were loaded onto a Dot blot manifold and bound to a nitrocellulose membrane filter. Membranes were blocked for 1 $\mathrm{h}$ in $3 \%(\mathrm{w} / \mathrm{v})$ dried skimmed milk in TBS containing $0.1 \%$ Tween-20 and incubated overnight in monoclonal antibody anti-MAO-A 6G11-E1 (tissue culture supernatant) at $4^{\circ} \mathrm{C}$. Membranes were washed and incubated for 2 at room temperature with phosphatase-conjugated anti-mouse immunoglobulin $\mathrm{G}$ (dilution 1:1000). Antibody binding was revealed in substrate buffer (0.75 M Tris, $\mathrm{pH}$ 9.5) containing $0.13 \mathrm{mM}$ nitroblue tetrazolium and $0.29 \mathrm{mM}$ bromochloroindolyl phosphate. Digital images were captured using a LAS-3000 image-analyser (Fuji Film Co. Ltd., Tokyo, Japan), and band intensity quantified using Aida software (Raytest GmbH, Straubenhardt, Germany).

\section{Detection of Reactive Oxygen Species (ROS)}

Cells were grown to $\sim 70-80 \%$ confluence on Lab-Tek (NUNC, Rosklide, Denmark) chamber slides prior to pre-treatment for $2 \mathrm{~h}$ with either serum free medium, $1 \mathrm{mM} \mathrm{N}$ - 
acetylcysteine (NAC) or $1 \mathrm{mM}$ Vitamin C. Medium was removed and replaced with Hanks Buffered Salt Solution (HBSS) containing $100 \mu \mathrm{M}$ DCDHF and incubated at $37^{\circ} \mathrm{C}$ for $50 \mathrm{~min}$. Following incubation the dye was replaced with either HBSS media alone (control), $500 \mu \mathrm{M}$ $\mathrm{H}_{2} \mathrm{O}_{2}$ (positive control) or $1 \mu \mathrm{M}$ STS in the presence or absence of $1 \mathrm{mM}$ NAC or $1 \mathrm{mM}$ Vitamin $\mathrm{C}$ for $1.5 \mathrm{~h}$. The concentration of anti-oxidants used was based on viability assays (using the MTT assay, data not shown) and information from previously published work (Spina et al. 1992). Changes in DCDHF fluorescence were monitored using a Leica CLSM inverted confocal laser scanning microscope. Increase in cytosolic dichloro-fluorescein (DCF) fluorescence reflected elevated intracellular ROS production. All images were taken using the same laser power, gain and objective.

\section{Immunohistochemistry}

Human liver sections $(4 \mu \mathrm{m})$ fixed in $2 \%(\mathrm{v} / \mathrm{v})$ para-formaldehyde in PBS for $4 \mathrm{~h}$, cryoprotected in $15 \%$ sucrose solution for $72 \mathrm{~h}$, or SH-SY5Y cells fixed in $90 \%(\mathrm{v} / \mathrm{v})$ ice cold methanol in TBS and incubated at $-20^{\circ} \mathrm{C}$ for $20 \mathrm{~min}$, were permeabilised with $0.5 \%(\mathrm{v} / \mathrm{v})$ Triton X-100 in PBS for 5 min at room temperature then washed in PBS. Slides were blocked for 20 min with $20 \%(\mathrm{v} / \mathrm{v})$ normal swine serum in PBS and then incubated overnight in monoclonal antibody, anti-MAO-A (6G11-E1) or anti-MAO-B (3F12-G10-2E3) (tissue culture supernatants), or PBS as a negative control at room temperature. The slide was washed in PBS and then incubated with secondary antibody; horseradish peroxidase conjugated anti-mouse immunoglobulin $\mathrm{G}$ (dilution 1:100) in $5 \% \mathrm{v} / \mathrm{v}$ normal swine serum in PBS for $30 \mathrm{~min}$ at room temperature. The slide was washed in PBS and antibody binding revealed by incubation in DAB substrate for 40 min and stopped with excessive washing in cold water. 


\section{Quantitative and conventional RT-PCR}

Total RNA was isolated from SH-SY5Y cells using the RNeasy Mini Kit (Qiagen, Hilden, Germany) and was reversely transcribed into the corresponding cDNA using oligo d(T) ${ }_{18}$ and Superscript II reverse transcriptase (Invitrogen, Karlsruhe, Germany) according to the vendors instructions. Quantitative PCR was carried out with a Bio-Rad iCycler system, using the iQ SYBR Green Supermix kit from Bio-Rad (Bio-Rad, California, U.S.A). The following primers were used: MAO A, 5'-GCC CTG TGG TTC TTG TGG TAT GT-3', 5'-TGC TCC TCA CAC CAG TTC TTC TC-3' and GAPDH, 5'-CCA TCA CCA TCT TCC AGG AGC GA3', 5'-GGA TGA CCT TGC CCA CAG CCT TG-3' and the following PCR protocol applied: 3 min initial denaturation and activation of the iTaq DNA polymerase at $95^{\circ} \mathrm{C}$, followed by 45 cycles of denaturation $\left(20 \mathrm{~s}\right.$ at $\left.95^{\circ} \mathrm{C}\right)$, annealing $\left(30 \mathrm{~s}\right.$ at $\left.65^{\circ} \mathrm{C}\right)$ and elongation $\left(30 \mathrm{~s}\right.$ at $\left.72^{\circ} \mathrm{C}\right)$. After that melting curve analysis was performed in order to confirm the homogeneity of the PCR product by continuous measuring and slowly decreasing the temperature from $95^{\circ} \mathrm{C}$ to $60^{\circ} \mathrm{C}$. For exact quantification standard curves were generated for each target gene used as external standards. Specific amplicons of each target gene were cloned into the vector pCR2.1 (Invitrogen, Karlsruhe, Germany) following the vendors instruction, sequenced and serial dilutions $\left(1 \times 10^{6}-1 \times 10^{2}\right.$ single stranded DNA molecules $)$ were prepared and used as template applying the above quantitative PCR approach. GAPDH mRNA was used as internal standard to normalize MAO-A mRNA. Each sample was run in duplicate and the results represent the mean of three independent sets of experiments.

Conventional PCR was performed with a TECHNE TC-412 thermal cycler, using the Advantage 2 Polymerase Mix (Takara Bio Europe, France) according to the vendor's instructions. After 32 
PCR cycles PCR products were separated on a $2 \%$ agarose gel in 1×TAE buffer (40 mM Tris$\mathrm{HCl}, \mathrm{pH} 8.1 ; 0.2 \mathrm{mM}$ EDTA; $20 \mathrm{mM}$ acetic acid $)$ in the presence of ethidium bromide $(0.2$ $\mu \mathrm{g} / \mathrm{ml}$ ). The gel was visualised with the GENE Genius Imaging System, using the GeneSnap software (version 5, SynGene, United Kingdom).

\section{Statistical Analysis}

All data shown are mean corrected values \pm SEM and statistical analysis was performed using the Student's unpaired t-test to identify significant data, where confidence values $(p$ values) of $<0.05,<0.01$, and $<0.001$ are marked by $*, * *$ and $* * *$ respectively.

\section{RESULTS}

\section{The MAO-A isoform is predominant in SH-SY5Y cells}

Dopaminergic SH-SY5Y cells have previously been reported to contain both MAO isoforms (Song and Ehrich, 1998); whilst others (Yi et al. 2006) have suggested the presence of only MAO-A in these cells. This prompted us to initially characterise the expression of MAO isoforms in our cell model. MAO activity was measured in vitro in SH-SY5Y cell homogenates following titration with specific and irreversible inhibitors of MAO-A (clorgyline) and MAO-B (deprenyl) (Fig. 1A). Complete inhibition of MAO activity was achieved with $10^{-8} \mathrm{M}$ clorgyline, whereas $10^{-5} \mathrm{M}$ deprenyl was required to inhibit MAO (Fig. 1A), suggesting MAO-A prevalence in this cell line. Clorgyline has previously been shown to inhibit MAO-A activity in in situ experiments using SH-SY5Y cells at a concentration of $10^{-6} \mathrm{M}$ (Yi et al. 2006). To support our activity assays, expression of the MAO isoforms was investigated at the protein and messenger 
level. Analysis of MAO-A protein involved the use of a MAO-A specific monoclonal antibody, previously characterised and shown to be useful for both immunohistochemistry (Church et al. 1994; Rodriguez et al. 2000) and quantitative immunoassays (Sivasubramaniam et al. 2002), whilst MAO-B protein was detected using a MAO-B-specific antibody (Billett and Mayer, 1986). MAO-A but not MAO-B protein was detected in SH-SY5Y cells (Fig. 1B) using immunohistochemical analysis with specific anti-MAO-A and MAO-B monoclonal antibodies. In contrast, control human liver sections exhibited positive staining for MAO-A and -B (Fig. 1B). Semi-quantitative reverse transcription-polymerase chain reactions (RT-PCR) revealed an intense signal for MAO-A indicating strong expression of the MAO-A messenger (Fig. 1C). In contrast, no signal was observed for MAO-B messenger. Finally, using the more sensitive approach of quantitative RT-PCR (qRT-PCR), average MAO-A mRNA expression of 2.58 \pm 1.00 molecules/1000 molecules GAPDH was measured, whereas MAO-B mRNA levels were hardly detectable (0.0006 \pm 0.0005 molecules/1000 molecules GAPDH, data not shown).

\section{STS induces an increase in MAO-A catalytic activity and protein levels prior to activation}

\section{of caspase 3}

In order to establish a model of neuronal apoptosis, SH-SY5Y cells were induced to undergo apoptotic cell death via the addition of staurosporine (STS). Initial titration studies established that $1 \mu \mathrm{M}$ STS produced apoptotic cell morphologies (cellular blebbing etc.), but the cells were still viable after $6 \mathrm{~h}$ (MTT reduction assay, data not shown). Treatment with $1 \mu \mathrm{M}$ STS consistently resulted in caspase-3 activation (approximately 7 fold of control levels at 3-6 h, Fig. 2). In addition, caspase-3 activation was preceded by a significant (2-3 fold) increase in MAO catalytic activity, suggesting that increased MAO activity could play a role in early 
apoptotic events. Increased MAO activity was associated with a significant but transient increase in MAO-A protein (2-3 fold, Fig. 3A).

\section{MAO-A mRNA expression is not changed in STS-induced apoptosis}

Quantitative reverse transcription-polymerase chain reactions (qRT-PCR) were performed to determine whether increases in MAO-A protein and activity were a result of increased MAO-A mRNA expression. No significant changes in MAO-A mRNA steady state levels were detected following $1 \mu \mathrm{M}$ STS treatment over a three-h apoptotic time course (Fig. $3 B)$.

\section{The intrinsic but not the extrinsic pathway is active in STS-induced Apoptosis}

To investigate the upstream initiators of caspase-3, activation of caspase- 8 and caspase- 9 was monitored by Western blotting using specific antibodies directed against both the pro- and active-forms of caspases- 8 and -9 . Caspase- 9 was activated, one $\mathrm{h}$ following STS exposure and remained active for the following $5 \mathrm{~h}$ (Data not shown; see Fig. 4 for $3 \mathrm{~h}$ time point). However, no activation of caspase- 8 was detected, despite the presence of caspase 8 protein and caspase- 8 mRNA as detected by Western blot and qRT-PCR respectively (data not shown).

\section{Inhibition of MAO-A protects cells from STS-induced apoptosis}

The MAO inhibitors clorgyline and tranylcypromine both inhibit in situ MAO activity in SH-SY5Y cells in the presence and absence of STS during a $4 \mathrm{~h}$ time period (Fig. 4A). Caspase3 activity was measured following inhibition of MAO-A in this apoptotic model to investigate the relevance of $\mathrm{MAO}$ in the apoptotic cascade. Both clorgyline and tranylcypromine 
significantly reduced caspase- 3 activation by $50 \%$ and $35 \%$ respectively (Fig. 4B). Activation of the upstream initiator Caspase-9 during STS-induced apoptosis was significantly reduced to $\sim 50 \%$ by clorgyline, compared to STS treated cells alone (Fig. 4C).

Inhibition of MAO-A also improves the viability of STS treated cells. Cell viability, measured using the MTT reduction assay, was reduced by $10 \%$ over a 3 -h exposure to STS. The MAO inhibitors clorgyline and tranylcypromine reduced this effect, which was significant after 1 h (supplementary data, Figure S1A). Morphological observations also demonstrated that inhibition of MAO-A improved viability. Figure S1B shows that after 3-h exposure, STS treatment results in a typical apoptotic phenotype, with cells being shrunk and rounded (compare panels a and $\mathrm{d}$ ). The addition of clorgyline and tranylcypromine at the same time as STS significantly improved the condition of the cells, with axonal outgrowths being evident (compare panels $\mathrm{b}$ and $\mathrm{c}$ with respectively panels e and $\mathrm{f}$ ).

\section{Involvement of MAPK signalling pathways in MAO-enhanced apoptosis}

MAPK phosphorylation cascades are activated following oxidative stress (Finkel, 1998), are involved in the activation of MAO-B expression (Wong et al. 2002) and in pro-apoptotic MAO-A expression (DeZutter and Davis, 2001). To examine the potential involvement of MAPK signalling in MAO-enhanced apoptosis, we investigated the levels of phosphorylated (activated) protein kinases ERK, JNK and p38 during STS induced apoptosis. As shown in Figure 5A, STS resulted in sustained increases in the levels of phosphorylated ERK, JNK and p38 compared to controls, starting at approximately the same time as MAO activation (Figure 2). Inhibition of MAO-A with clorgyline attenuated these effects, reducing the levels of 
phosphorylated p38, JNK and ERK back to control levels. These data suggest that MAPK signalling pathways are likely to be important in MAO-mediated apoptosis.

\section{Inhibition of MAO-A prevents Bcl-2 depletion during STS-Induced apoptosis}

The Bcl-2 family of proteins are critical in apoptotic signalling because of their anti- and pro-apoptotic effects at the mitochondrial surface. As seen in Figure 5B, STS induced depletion of Bcl-2 levels and clorgyline alone had no effect on Bcl-2 levels. When the cells were exposed to clorgyline and STS together, Bcl-2 protein expression was maintained at the control level (Fig. $5 B)$.

Inhibition of MAO-A and addition of antioxidants has a similar effect on ROS formation and caspase- 3 activation

MAO-A produces $\mathrm{H}_{2} \mathrm{O}_{2}$ as a by-product of its enzymatic action. We hypothesised that MAO-A derived ROS might contribute to apoptotic signalling in our cell model. Hence antioxidants should mimic the effect of MAO-A inhibition in apoptotic signalling. Exposure of SH-SY5Y cells to $1 \mu \mathrm{M}$ STS resulted in the production of high levels of ROS. This effect was lessened by concomitant treatment with $1 \mu \mathrm{M}$ clorgyline or the anti-oxidant $\mathrm{N}$-acetyl cysteine (NAC, $1 \mathrm{mM}$ ). However, $1 \mathrm{mM}$ vitamin $\mathrm{C}$ was less effective (Fig. 6A). NAC but not vitamin $\mathrm{C}$ significantly protected cells from caspase-3 activation (Fig. 6B). These data indicate that MAOgenerated oxidative stress is involved in apoptotic signalling. 


\section{DISCUSSION}

In SH-SY5Y cells staurosporine activates caspase-9 and -3 and thus initiates the intrinsic apoptotic pathway. In contrast, the extrinsic route, which depends on agonist binding to cell surface death receptors, remained unaffected, despite the cells containing caspase 8 protein and also caspase 8 mRNA (data not shown). These data are consistent with previously reported results obtained in a similar cellular model (Lopez and Ferrer, 2000). The activation of the mitochondrial apoptotic pathway in this model is of special interest considering the intracellular localisation of MAO in the outer mitochondrial membrane.

Our studies demonstrated that MAO-A activity was increased prior to caspase-3 activation and that inhibition of MAO activity significantly reduced caspase activation and loss in cell viability. To improve the reliability of our experimental data we used two independent MAO inhibitors with different modes of action. Clorgyline preferentially inhibits MAO-A, but is structurally related to the MAO-B inhibitor deprenyl and other propargyl deprenyl analogues such as $N$ propargyl-1(R)-aminoindan (rasagiline) and the compound CGP3466 (now in clinical trials for PD). The propargylamine-containing deprenyl analogues have been reported to posses neuroprotective and anti-apoptotic properties (Holt et al. 2004; Akao et al. 2002; Tatton et al. 1994). These neuroprotective properties, rather than being a result of MAO inhibition, are thought to be due, at least partly, to the inhibition of pro-apoptotic translational machinery (Kragten et al. 1998; Berry and Boulton, 2000), and induction of anti-apoptotic Bcl-2 family proteins (Kragten et al. 1998). Clorgyline has previously been shown to protect against apoptosis (DeZutter and Davis, 2001), serum withdrawal-induced loss in cell viability (Ou et al. 2006) and MPTP induced neurotoxicity (DeGirolamo et al. 2001). Whether or not the protective effects are 
due solely to MAO inhibition has not been investigated. Indeed in our system clorgyline had no effect on Bcl-2 levels, at least in control cells. To confirm that the effects of clorgyline were a result of MAO inhibition, tranylcypromine was used as a second MAO inhibitor since it contains no propargyl moiety, but interacts irreversibly with the flavin group. Tranylcypromine inhibits both MAO-A and MAO-B but, because of the lack of MAO-B expression in our cell model, the protection of the cells from apoptosis can be attributed to its inhibition of MAO-A. This confirms that MAO-A is functional in neuronal cell apoptosis. Although a link between MAO and mitochondrial damage is well established (Berman and Hastings, 1999; Cohen and Kesler, 1999) and mitochondria are vital players in apoptotic signalling, a direct role for MAO-A in apoptosis has only been claimed by De Zutter and Davis (2001) and, very recently, by Ou (Ou et al. 2006). However, these authors did not attempt to link the apoptotic effects to ROS production by MAOA activity.

ROS formation was substantially increased following STS treatment and inhibition of MAO by clorgyline and treatment with the antioxidant $\mathrm{N}$-acetyl cysteine (NAC, a precursor of glutathione and an anti-oxidant in its own right) reduced ROS to a similar extent. The fact that both clorgyline and NAC also reduced caspase-3 activation indicates that ROS are the result of MAO activity. The anti-oxidant vitamin $\mathrm{C}$ was also used but was less effective than NAC or clorgyline in reducing both ROS production and caspase- 3 activation. The reason for this is not clear but it may be related to the fact that vitamin $\mathrm{C}$, although a potent anti-oxidant, is considered to be toxic in some circumstances, especially in the presence of metal ions and $\mathrm{H}_{2} \mathrm{O}_{2}$ (reviewed by Halliwell, 1999). 
MAO may be important in the early phase of apoptosis, before the execution of downstream processes, since peak MAO activity and ROS production occur prior to peak caspase-3 activity. Apoptosis is highly regulated, the mechanisms of which are still not fully understood, not only because there is a wide range of cell death types ranging between classical apoptosis to classical necrosis, but also because of variation depending on the nature of the inducer. However it is thought that apoptosis is the predominant form of neuronal cell death in chronic neurodegenerative diseases (Emerit et al. 2004). Thus the fact that MAO has an active role in this process is of high significance.

We also demonstrate that MAO protein levels are increased, albeit transiently, and without a concomitant increase in MAO-A mRNA levels. This implies that in our apoptotic model, increases in MAO protein are due to post-transcriptional events. This could include a decrease in MAO protein degradation or an increase in mRNA translation. However little is known about these processes. In contrast, transcriptional activation of the MAO-A gene was seen following withdrawal of nerve growth factor in rat PC12 cells (DeZutter and Davis, 2001, which has been related to pro-apoptotic signalling) and in SH-SY5Y cells (Fitzgerald et al, 2007). In addition, $\mathrm{Ou}$ and co-workers (2006) recently found that MAO-A mRNA expression is also induced following serum starvation, mediated by a reduction in the expression of the transcriptional repressor R1. These different findings suggest that there are various regulatory mechanisms of cell death that could regulate MAO-A expression at different levels of gene expression.

Bcl-2 is an anti-apoptotic protein that plays a central role in mitochondrially mediated-apoptosis and survival due to its strong influence on the balance of pro- and anti-apoptotic proteins that 
also reside on the mitochondrial surface. Depletion of Bcl-2 is thought to be one of the first initiators of the apoptotic cascade, since this shifts the balance of Bcl-2 family proteins in favour of apoptosis, triggering the release of cytochrome $c$ from the mitochondria (Hengartner, 2000). STS exposure resulted in depletion of Bcl-2 levels in our model and was prevented by clorgyline, suggesting that MAO is acting upstream of Bcl-2. This is contrary to the situation in serum withdrawal, where MAO appears to act downstream of Bcl-2 (Ou et al. 2006). However, these differences may reflect the different apoptotic inducers used and further work needs to be carried out to clarify this.

The highly conserved mitogen-activated protein kinase (MAPK) cascades (Robinson and Cobb, 1997) are among the pathways often used to transduce mammalian stress signals. They have been extensively described as crucial in regulating stress/survival responses and hence play an important and universal role in mechanisms of cell death. Following STS-induced apoptosis the extracellular regulated kinase (ERK), thought to be activated by mitotic stimuli was activated, co-inciding with increases in MAO-A activity (Figures 2 and 5). Activation of p38 and c-jun Nterminal kinase (JNK) generally activated by pro-inflammatory or stressful stimuli, also occurred at the same time as ERK. MAO inhibition by clorgyline attenuated the activation of these pathways to control levels. Thus MAPK signalling modules are involved in STS induced apoptosis and ROS generated by MAO are involved in initiating these pathways (since MAO inhibition reduced MAPK activation). Indeed $\mathrm{H}_{2} \mathrm{O}_{2}$ (a product of a MAO catalysed reaction) has previously been shown to activate MAPK proteins (Guyton et al. 1996). Whether or not the MAO gene is also a target of the MAPK pathways as described by DeZutter and Davis (2001) and Wong (Wong et al. 2002) was not addressed in the present paper, but would seem unlikely 
given that MAO mRNA levels were unchanged following STS treatment. However, in our model it is clear that MAPK signalling is recruited to transmit pro-apoptotic stress signals following STS exposure.

In conclusion, data in this report suggest a dynamic role for MAO-A in STS-induced neuronal apoptosis, driven by the ability of MAO to generate oxidative stress in its prime position on the mitochondrial surface. Our data support the supposition that MAO plays a key role in the modulation of apoptotic signalling in response to biological stressors. These findings may have wider implications for the therapeutic use of the dopamine precursor, levodopa, in PD and predisposition to neurodegenerative diseases.

\section{ACKNOWLEDGEMENTS}

This work was supported by grants from The British Council, Deutscher Akademischer Austauschdienst (DAAD) and The Leverhulme Trust.

\section{REFERENCES}

Abou-Sleiman, P. M., Muqit, M. M. K. and Wood, N. W. (2006). Expanding insights of mitochondrial dysfunction in Parkinson's disease. Nature Neuroscience 7, 207-219.

Akao, Y., Maruyama, W., Yi, H., Shamoto-Nagai, M., Youdim, M., B. H, and Naoi, M. (2002). An anti-Parkinson's disease drug, N-propargyl-1(R)-aminoindan (Rasagiline), enhances expression of anti-apoptotic Bcl-2 in human dopaminergic SH-SY5Y cells. Neurosc. Lett. 326, $105-108$ 
Bach, A. W. J., Lan, N. C., Johnson, D. L., Abell, C. W., Bembenek, M. E., Kwan, S., Seeburg, P. H., and Shih, J. C. (1988). cDNA cloning of human liver monoamine oxidase A and B: Molecular basis of differences in enzymic properties. Proc. Natl. Acad. Sci. USA. 85, 4934-4938

Berman, S. B., and Hastings, T. G. (1999). Dopamine oxidation alters mitochondrial respiration and induces permeability transition in brain mitochondria: Implications for Parkinson's Disease. J. Neurochem. 73, 1127-1137

Berry, M., D, and Boulton, A. A. (2000). Glyceraldehyde-3 Phosphate Dehydrogenase and apoptosis. J. Neurosc. Res. 60, 150-154

Billett, E. E. (2004). Monoamine Oxidase (MAO) in human peripheral tissues. Neurotoxicology. 25, 139-148

Billett, E.E. and Mayer, R.J. (1986). Monoclonal antibodies to monoamine oxidase B and another mitochondrial protein from human liver. Biochem. J. 235, 2157-2163

Cadenas, E., and Davies, K. J. A. (2000). Mitochondrial free radical generation, oxidative stress, and aging. Free Rad. Biol. Med. 29 (3/4), 222-230

Church, R.J., Robinson, G. and Billett, E.E. (1994). The localisation of monoamine oxidase in human placenta using a new specific monoclonal antibody to monoamine oxidase A. Proc. R. Microsc. Soc. 29, 243.

Cohen, G., and Kesler, N. (1999). Monoamine oxidase and mitochondrial respiration. J. Neurochem. 73, 2310-2315

De Girolamo, L. A., Hargreaves, A. J. and Billett, E. E. (2001). Protection from MPTP-induced neurotoxicity in differentiating mouse N2a neuroblastoma cells. J. Neurochem. 76, 650660 
DeZutter, G. S., and Davis, R. J. (2001). Pro-apoptotic gene expression mediated by the p38 mitogen-activated protein kinase signal transduction pathway. Proc. Natl. Acad. Sci. USA. 98(11), 6168-6173

Emerit, J., Edeas, M., and Bricaire, F. (2004). Neurodegenerative diseases and oxidative stress. Pharmacotherapy. 58, 39-46

Finkel, T. (1998). Oxygen radicals and signaling Curr. Opinion in Cell Biology. 10, 248-252

Fitzgerald, J. C., Ufer, C and E, E. Billett. 2007. A link between monoamine oxidase-A and apoptosis in serum deprived human SH-SY5Y neuroblastoma cells. J. Neural. Transm. 114(6), 807-810.

Fowler, C. J., and Tipton, K. F. (1984). On the substrate specificities of the two forms of monoamine oxidase J. Pharm. Pharmacol. 36(2), 111-115

Guyton, K. Z., Liu, Y., Gorospe, M., Xu, Q., and Holbrook, N. J. (1996). Activation of Mitogen activated Protein Kinase by $\mathrm{H}_{2} \mathrm{O}_{2}$. J. Biol. Chem. 271(8), 4138-4142

Halliwell, B. 1999. Vitamin C: poison, prophylactic or panacea? TIBS. 24, 255-259.

Hauptmann, N., Grimsby, J., Shih, J. C. and Cadenas, E. (1996). The metabolism of tyramine by monoamine oxidase A/B causes oxidative damage to mitochondrial DNA. Arch. Biochem. Biophys. 335, (295-304)

Hengartner, M. O. (2000). The biochemistry of apoptosis. Nature. 407, 770-776

Holt, A., Berry, M., D, and Boulton, A. A. (2004). On the binding of monoamine oxidase inhibitors to some sites distinct from the MAO active site, and effects thereby elicited. Neurotoxicol. 25, 251-266

Kragten, E., Lalande, I., Zimmermann, K., Roggo, S., Schindler, P., Muller, D., Van Oostrum, J., and Furst, P. (1998). Glyceraldehyde-3-phosphate Dehydrogenase, the putative target of 
the anti-apoptotic compounds CGP 3466 and R-(-)-Deprenyl. J. Biol. Chem. 273(10), $5821-5828$

Kumar, M. J., Nicholls, D. G., and Anderson, J. K. (2003). Oxidative Alpha-Ketoglutarate Dehydrogenase inhibition via subtle elevations in Monoamine Oxidase B levels results in loss of spare respiratory capacity. J. Biol. Chem. 278(47), 46432-46439

Lowry, O. H., Rosebrough, N. J., Farr, A. L., and Randall, R. J. (1951). Protein measurement with the Folin phenol reagent. J. Biol. Chem. 193, 265-275

Lopez, E., and Ferrer, I. (2000). Staurosporine- and H-7-induced cell death in SH-SY5Y neuroblastoma cells is associated with caspase- 2 and caspase- 3 activation, but not with the activation of the FAS/FAS-L-caspase-8 signaling pathway. Brain Res. Mol Brain Res. $\mathbf{8 5}(1-2), 61-67$

Ou, X., Chen, K., and Shih, J. C. (2006). Monoamine oxidase A and repressor R1 are involved in apoptotic signaling pathway. Proc. Natl. Acad. Sci. USA. 103(29), 10923-10928

Riederer, P., Sofic, E., Rausch, W. D., Schmidt, B., Reynolds, G. P., Jellinger, K., and Youdim, M. B. (1989). Transition metals, ferritin, glutathione, and ascorbic acid in Parkinsonian brains. J. Neurochem. 52(2), 515-520

Robinson, M. J., and Cobb, M. H. (1997). Mitogen activated protein kinase signalling pathways. Curr. Opin. Cell. Biol. 9, 180-186

Rodriguez, M.J., Saura, J., Finch, C., Mahy, N.and Billett, E.E. (2000). Localization of monoamine oxidase -A and -B in human pancreas, thyroid and adrenal glands. J. Histochem. Cytochem., 48 (1), 147-151.

Russell, S. M., and Mayer, R. J. (1983). Degradation of transplanted rat liver mitochondrialouter-membrane proteins in hepatoma cells. Biochem. J. 216, 163-175 
Schulz, J. B., Lindenau, J., Seyfried, J., and Dichgans. (2000). Glutathione, oxidative stress and neurodegeneration. Eur. J. of Biochem. 267, 4904-4911

Shih, J. C., Chen, K., and Ridd, M. J. (1999). Monoamine oxidase: From genes to behavior. Ann. Rev. Neuroscience. 22, 197-217

Sivasubramaniam, S.D., Finch, C.C, Billett, MA, Baker PH and Billett E.E. (2002). Monamine oxidase expression and activity in human placentae from pre-eclamptic and normotensive pregnancies. Placenta 23 (2-3), 163-171.

Song, X., and Ehrich, M. (1998). Uptake and metabolism of MPTP and MPP ${ }^{+}$in SH-SY5Y human neuroblastoma cells. In Vitro Mol. Toxicol.(1), 3-12

Spina, M. B., Squinto, S. P., Miller, J., Lindsay, R. M. And Hyman, C. (1992). Brain-Derived Neurotrophic Factor protects dopamine neurons against 6- Hydroxydopamine and NMethyl-4-Phenylpyridinium ion toxicity: involvement of the glutathione system. $J$. Neurochem. 59(1), 99-106.

Stokes, A. H., Hastings, T. G. and Vrana, K. E. (1999). Cytotoxic and genotoxic potential of dopamine. J. Neurosci. Res. 55, 659-665

Tatton, W. G., Ju, W. Y. L., Holland, D. P., Tai, C., and Kwan, M. (1994). (-)-Deprenyl reduces PC12 cell apoptosis by inducing new protein synthesis J. Neurochem. 63(4), 1572-157

Tatton, W. G., and Olanow, W. (1999). Apoptosis in neurodegenerative diseases: the role of mitochondria. Biochim. et Biophys. Acta 1410, 195-213

Wong, W. K., Ou, X., Chen, K., and Shih, J. C. (2002). Activation of human monoamine oxidase B gene expression by a Protein Kinase C MAPK signal transduction pathway involves cJun and Egr-1. J. Biol. Chem. 277(25), 22222-22230 
Yi, H., Akao, Y., Maruyama, W., Chen, K., Shih, J. C., and Naoi, M. (2006). Type A monoamine oxidase is the target of an endogenous dopaminergic neurotoxin, $\mathrm{N}$-methyl(R)salsolinol, leading to apoptosis in SH-SY5Y cells. J. Neurochem. 96, 541-549

Yoon, S., Yun, C., and Chung, A. (2002). Dose effect of oxidative stress on signal transduction in aging. Mech. Ageing Dev. 123, 1597-1604 


\section{Fitzgerald Figure 1}
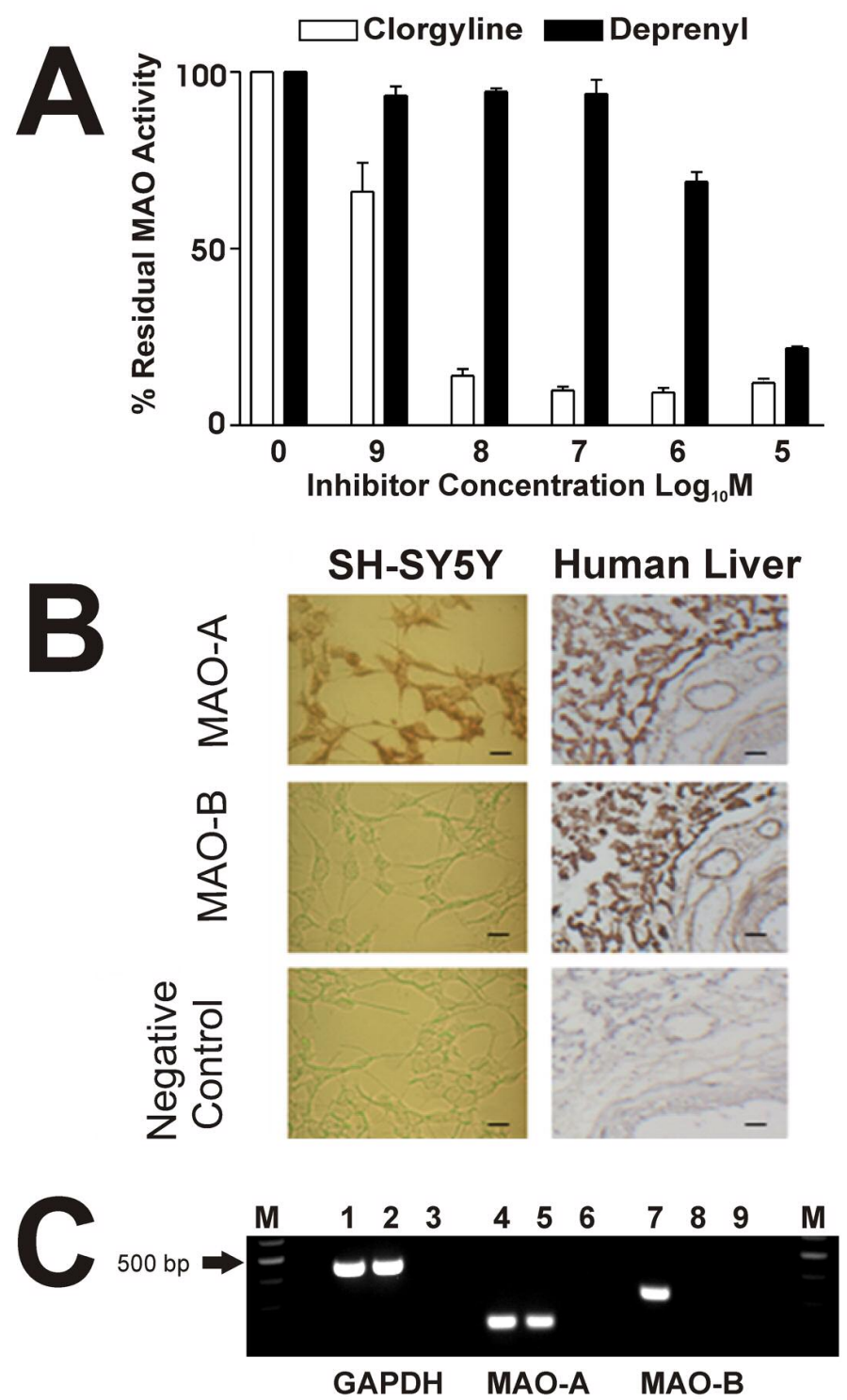

Fig. 1. MAO-A is predominant in SH-SY5Y human neuroblastoma cells (A) MAO Activity activity was measured following addition of $0,10^{-9}, 10^{-8}, 10^{-7}, 10^{-6}, 10^{-5} \mathrm{M}$ clorgyline or deprenyl to SH-SY5Y cells in vitro via a radiometric method using ${ }^{14} \mathrm{C}$-Tyramine as a substrate. Changes in MAO activity were determined in the presence or absence of the inhibitors and expressed \% residual activity. (B) Immunohistochemistry - SH-SY5Y cells and human liver sections were stained with MAO-A (6G11-E1) and MAO-B (3F12/G10/2E3) specific antibodies and revealed using 3,3'-Diaminobenzidine. Control sections were incubated in the absence of MAO-specific antibodies but revealed under the same conditions. MAO specific immunoreactivity is represented by dark brown/ red staining revealing the presence of MAO-A only in SH-SY5Y cells, but both MAO-A and MAO-B in human liver (control). The images shown are from a representative experiment. Scale bar represents $20{ }^{\mu} \mathrm{m}$. (C) RT-PCR - Agarose gel showing positive PCR controls (lanes 1,4 and 7), SH-SY5Y samples (lanes 2, 5 and 8) and negative PCR controls (lanes 
3, 6 and 9) for GAPDH, MAO-A and MAO-B gene expression. 


\section{Fitzgerald Figure 2}

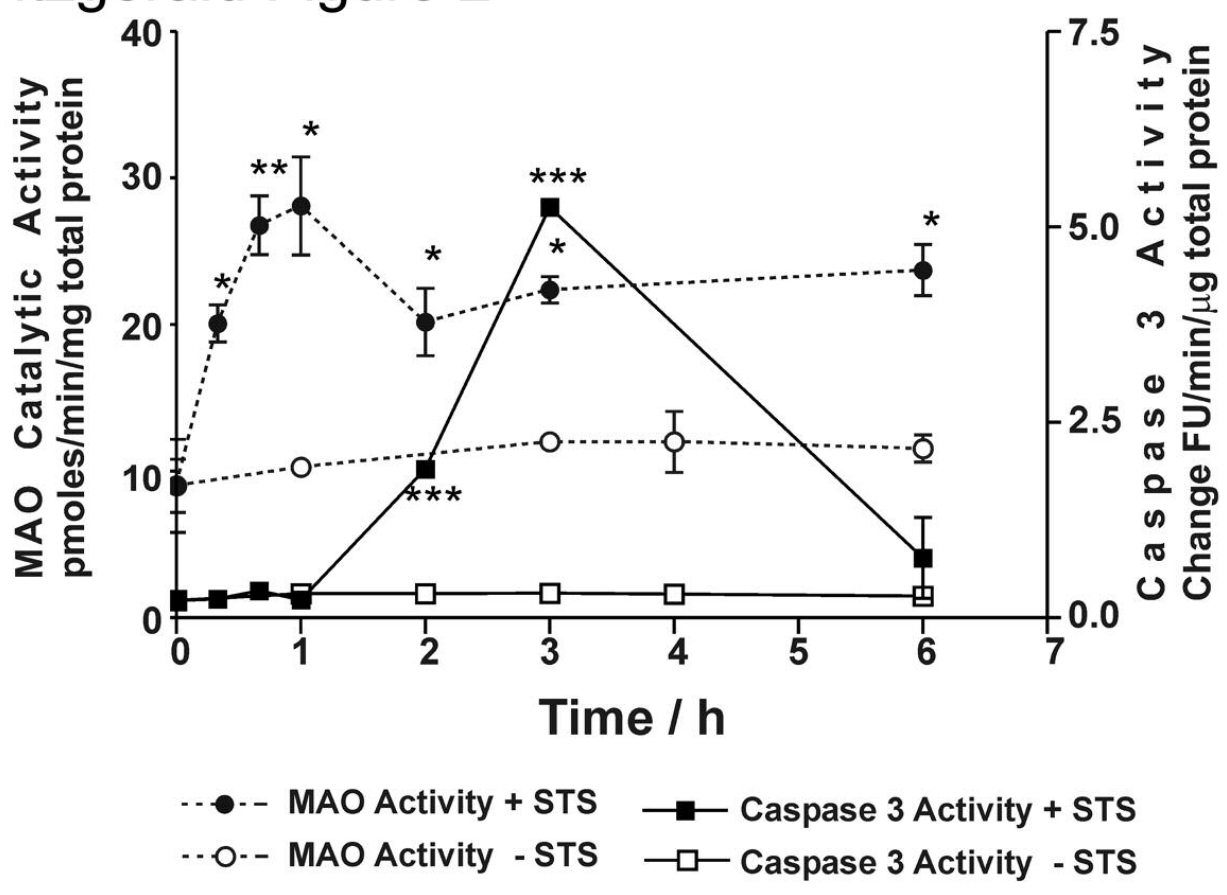

Fig. 2. Changes in MAO catalytic activity following STS treatment. Following addition of 1

${ }^{\mu}$ M STS, MAO activity was measured in SH-SY5Y via a radiometric method, using ${ }^{14} \mathrm{C}$ Tyramine as a substrate. MAO catalytic activity was expressed as pmoles $/ \mathrm{min} / \mathrm{mg}$ protein. Caspase-3 activation was measured to monitor the apoptotic time course, using Acetyl-Asp-Glu-Val-Asp-7-Amido methylcoumarin as substrate and expressed as $\Delta$

$\mathrm{FU} / \mathrm{min} /{ }^{\mu} \mathrm{g}$ protein. All data represent triplicate values from three independent experiments $(n=3)$ and are expressed as mean \pm S.D. Treated samples were statistically compared to untreated controls at time zero using the Student's t-test where $* p<0.05$, $* * p<0.01, * * * p<0.001$. 


\section{Fitzgerald Figure 3}
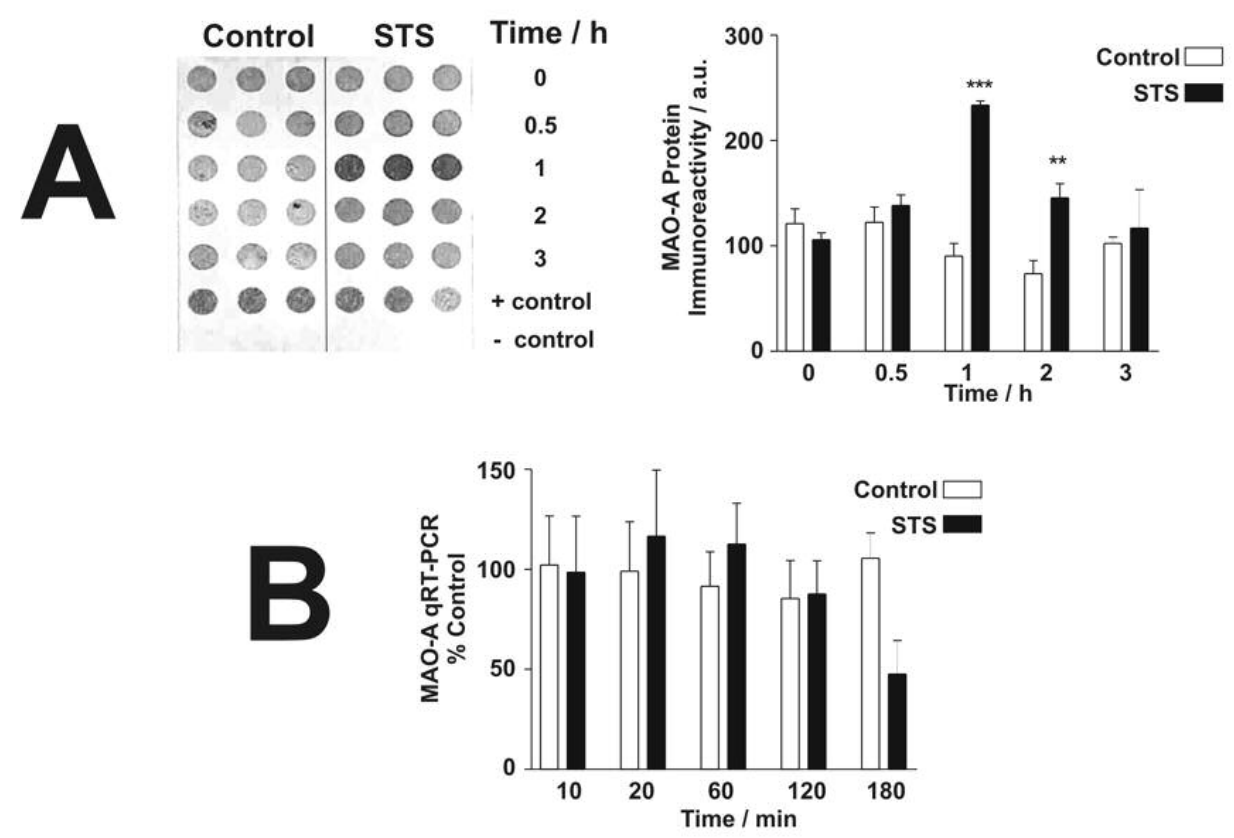

Fig. 3. MAO-A protein, but not MAO-A mRNA expression levels are induced by STS. (A) Left panel shows a dot blot of MAO-A protein levels following STS exposure. Equal protein homogenates were loaded on to a nitrocellulose membrane and probed with a MAO-A specific antibody. Mitochondrial outer membranes from human liver are the positive control and no primary antibody was the negative control. (A) Right panel. Quantification of blots in left panel. Blots were digitised and densitometry was performed to quantify relative MAO-A protein levels in all blots. These data represents values from four separate experiments $(n=4)$ and expressed as mean arbitrary units (a.u.) $\pm S$. D. Statistical analysis of treated cells in comparison to untreated controls was carried out using the Student's t test, where $* * p<0.01, * * * p<0.001$. (B) MAO-A mRNA expression was measured by qRT-PCR following the addition of $1 \mu$ M STS for $3 \mathrm{~h}$. Data represent duplicate values from three independent experiments $(n=3)$. Values are expressed as means ( $\%$ cf. untreated time zero control) \pm S.D. Statistical analysis of treated cells in comparison to untreated controls was performed using the Student's t-test, where no data was significant at $p<0.05$. 


\section{Fitzgerald Figure 4}
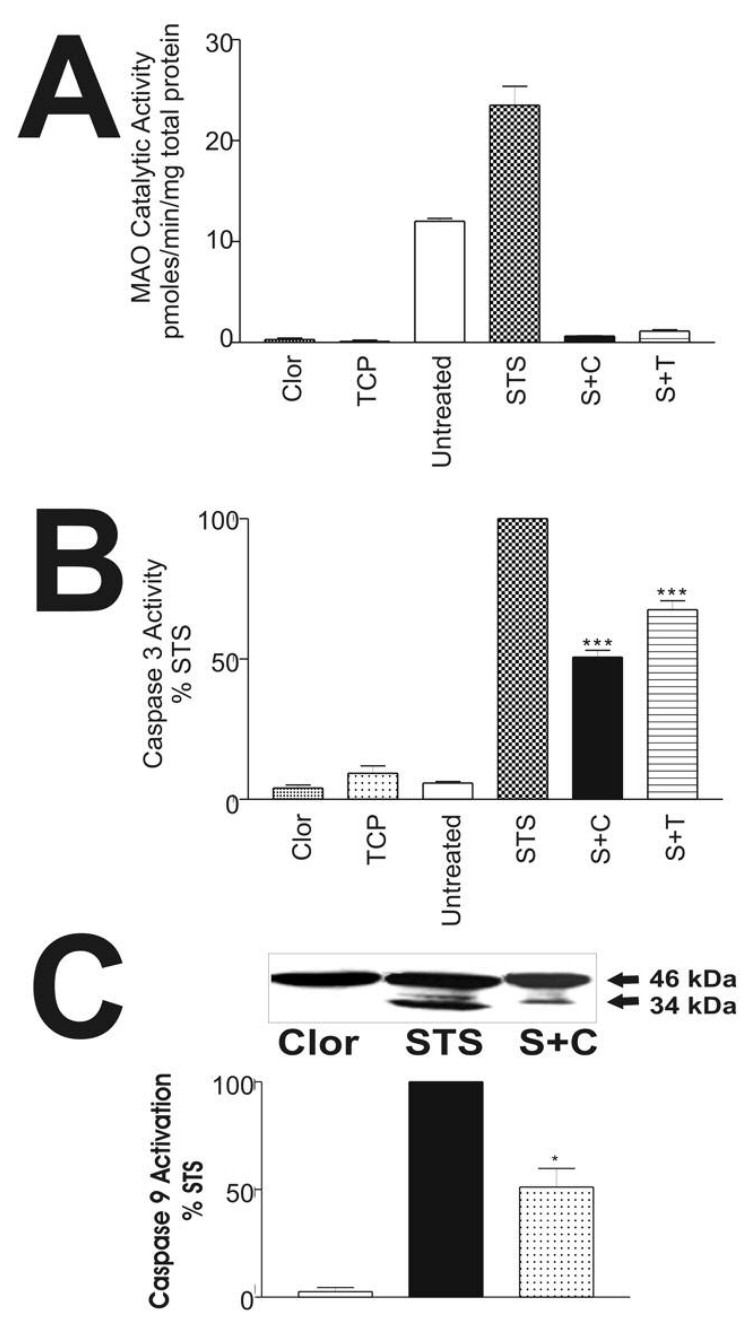

Fig. 4. Inhibition of MAO-A reduces caspase-3 activity and caspase-9 activation in STSinduced apoptosis (A) MAO activity was measured in SH-SY5Y cells, $3 \mathrm{~h}$ following the

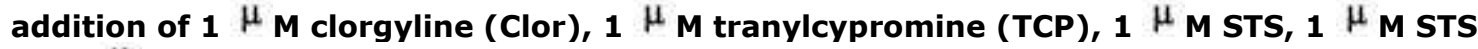
$+1 \mu_{M}$ clorgyline $(S+C)$ or tranylcypromine $(S+T)$, and in untreated cells, using ${ }^{14} \mathrm{C}-$ Tyramine as a substrate. Changes in MAO activity were determined and expressed as experimental mean pmoles $/ \mathrm{min} / \mathrm{mg}$ protein \pm S.D. (B) Caspase-3 activity was measured in SH-SY5Y cells, $3 \mathrm{~h}$ following the addition of $1 \mu_{\text {M clor, } 1} \mu_{\mathbf{M} \text { TCP, } 1} \mu_{\mathbf{M}}$ STS, S+C, $\mathbf{S}+\mathbf{T}$ and in untreated cells, using Acetyl-Asp-Glu-Val-Asp-7-Amido-methylcoumarin as a substrate. Caspase-3 activity was expressed as mean $\Delta \mathrm{FU} / \mathrm{min} /{ }^{\mu} \mathrm{g}$ protein \pm S.D, where $n=3$. MAO/Caspase activities from clorgyline treated cells were compared to activities from cells exposed to STS alone using the Student's t-test, where $* * p=0.01$, 
$* * * p=0.001$. (C) Western blot - activation of caspase-9 (pro-form/active form) was assessed in extracts of SH-SY5Y cells exposed to $1 \mu$ M STS in the presence or absence of $1 \mu$ M clorgyline following $3 \mathrm{~h}$ exposure. Equal protein aliquots $(20 \mu \mathrm{g})$ were separated on a $12 \%(\mathrm{v} / \mathrm{v})$ acrylamide SDS-PAGE gel prior to transfer to nitrocellulose filters. Blots were probed with anti-caspase-9 antibody $(2 \mu \mathrm{g} / \mathrm{ml})$. Western blot shown is a representative blot of three independent experiments. 


\section{Fitzgerald Figure 5}

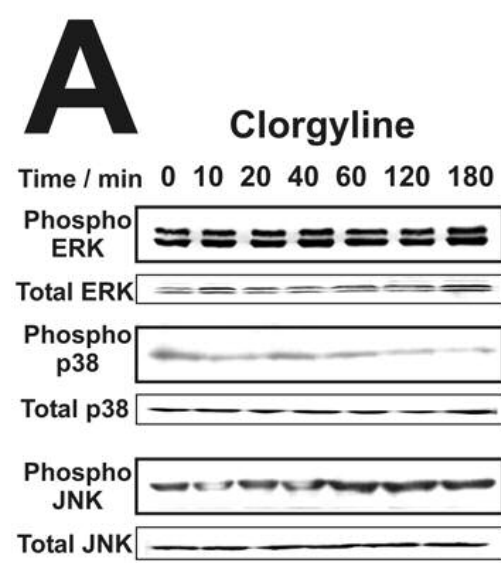

Clorgyline

Time $/ \min 0 \quad 10 \quad 20 \quad 4060 \quad 120180$

Bcl-2

Total ERK

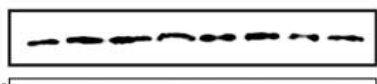

-
STS

$\begin{array}{lllllll}0 & 10 & 20 & 40 & 60 & 120 & 180\end{array}$

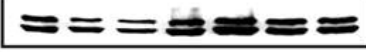

$==0$
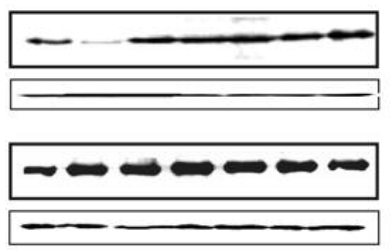

STS

$\begin{array}{lllllll}0 & 10 & 20 & 40 & 60 & 120 & 180\end{array}$

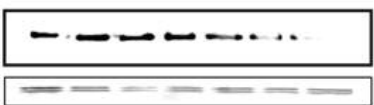

STS+Clorgyline

$\begin{array}{lllllll}0 & 10 & 20 & 40 & 60 & 120 & 180\end{array}$

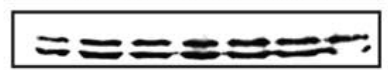

$=\equiv$
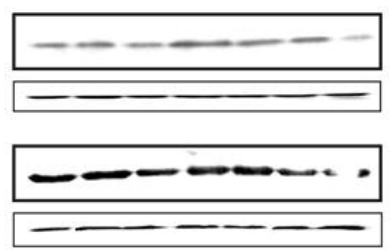

STS+Clorgyline

$\begin{array}{lllllll}0 & 10 & 20 & 40 & 60 & 120 & 180\end{array}$

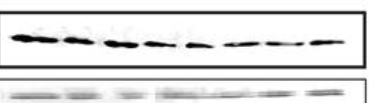

Fig. 5. STS induces changes in MAPK signalling and $\mathrm{Bcl}-2$ levels, which are attenuated by clorgyline. Equal protein aliquots (80 $\mu^{\mathrm{g}}$ for MAPK proteins and $20{ }^{\mu} \mathrm{g}$ for Bcl-2) of cells extracts from SH-SY5Y cells exposed to $1 \mu_{\text {M clorgyline, } 1} \mu_{\text {M STS or } 1} \mu_{\text {M STS }} 1 \mu$ M clorgyline for a $3 \mathrm{~h}$ period were separated on a $12 \%(\mathrm{v} / \mathrm{v})$ acrylamide SDS-PAGE gel prior to transfer to nitrocellulose membranes. Blots were probed with antibodies directed to pERK (1:1000 dilution), pJNK (1:500 dilution) and pP38 (1:1000) (A) or by anti-bcl-2

antibody (1:750) (B). Equal loading was checked by probing for total ERK (1:1000 dilution), total JNK (1:750 dilution) and total p38 (1:1000 dilution). Blots shown are representative of three separate experiments. 


\section{Fitzgerald Figure 6}
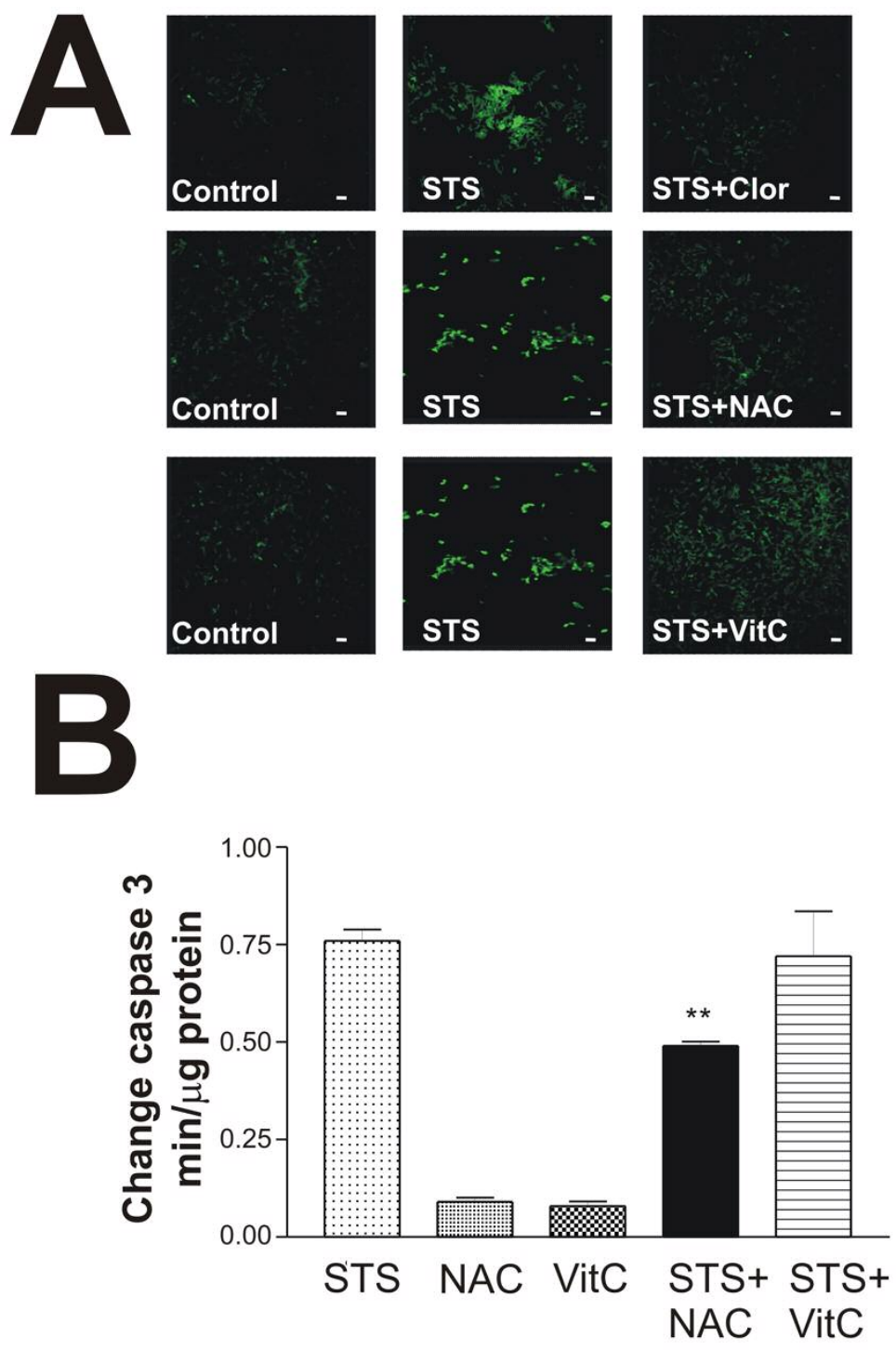

Fig. 6. Effect of clorgyline and antioxidants on ROS production in STS exposed SH-SY5Y cells. (A) Cells exposed to STS were treated with $1 \mu$ M Clorgyline, 1 mM NAC or 1 mM Vitamin $\mathrm{C}$ for $4 \mathrm{~h}$. DCDHF fluorescence was monitored over a $4 \mathrm{~h}$ period and visualised using a CLSM Leica microscope. Photomicrographs are shown at $1.5 \mathrm{~h}$ post-treatment and are representative of 3 independent experiments. Scale bar represents $20 \mu \mathrm{m}$. (B) The effect of antioxidants NAC and vitamin C on caspase-3 activity were measured in SH-SY5Y cells following treatment (see above) for $2 \mathrm{~h}$ and measured using Acetyl-Asp-Glu-ValAsp-7-Amidomethylcoumarin as a substrate. Caspase 3 activity was expressed as mean $\Delta \mathrm{FU} / \mathrm{min} /{ }^{\mu} \mathrm{g}$ protein $\pm \mathbf{S}$.D, where $n=3$. Statistical analysis of antioxidant treatment in the presence of STS was compared to STS treatment alone using the Student's t-test where $* * p<0.01$. 


\section{Page 35 of 32}

Journal of Neurochemistry

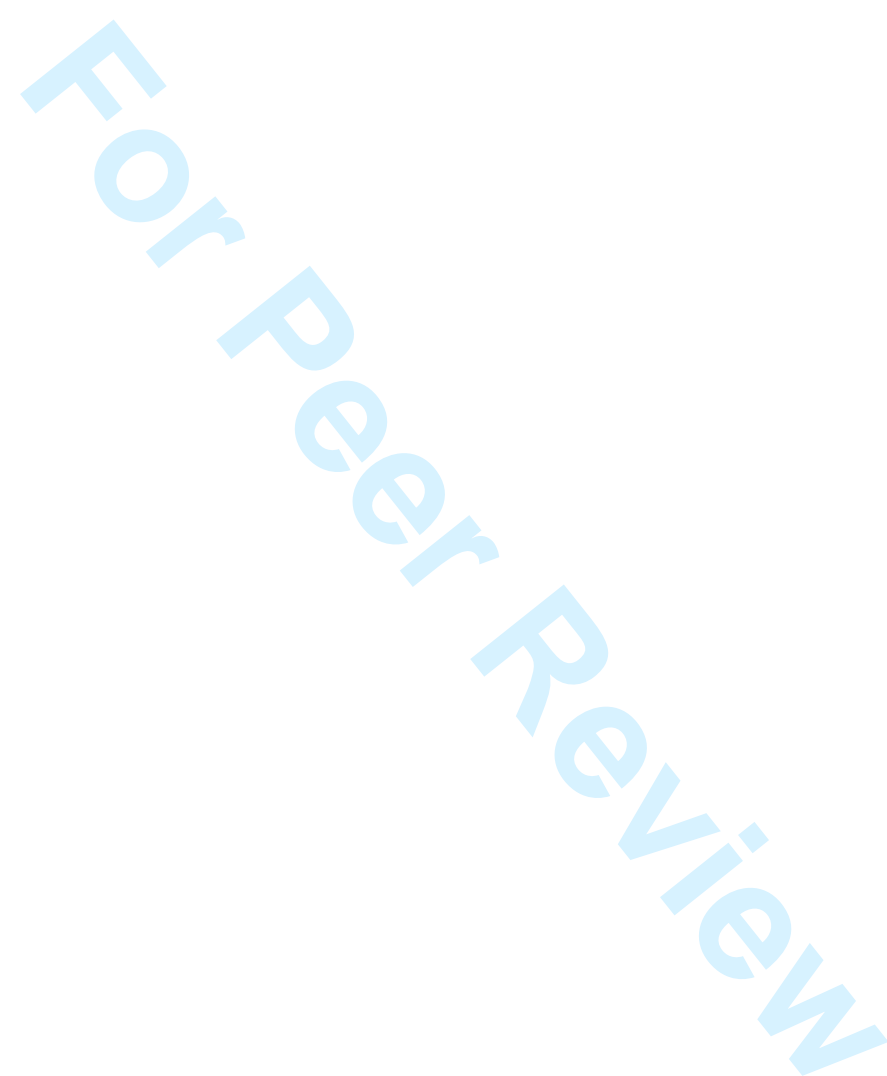

